\title{
Economics of Fruit Thinning: A Review Focusing on Apple and Citrus
}

\author{
Kathy Davis, Ed Stover, ${ }^{1}$ and \\ Ferdinand Wirth
}

Additional INDEX WORDS. cropload, fruit size, Malus, mandarin, NAA, PGR

\begin{abstract}
Summary. Hundreds of fruit thinning experiments have been reported for various fruits including apple (Malus $\times$ domestica) and citrus (Citrus spp.). Unfortunately, very few of these reports attempt to evaluate the economic implications of thinning. Researchers routinely report significant cropload reduction accompanied by an increase in fruit size. Although these are crucial responses to thinning, they are not always associated with an increase in crop value, which is the commercial justification for thinning. The few economic studies summarized in this review illustrate that the economic effects of fruit thinning vary widely, and successful thinning often reduces returns to the grower, at least in the year of treatment. It is important to quantify the economic benefits of thinning and identify croploads that balance the trade-off between yield and fruit size to provide optimal crop value. Future thinning research should report total yields and fruit size distributions to permit economic assessments and comparisons of treatments.
\end{abstract}

$\mathrm{T}$ The practice of fruit thinning has been used for hundreds, perhaps thousands, of years to manipulate cropping and blooming in apple, pear (Pyrus communis), and peach (Prunuspersica) (Dennis, 2000). These fruit trees and others, including some cultivars of citrus, tend to develop a pattern of biennial bearing that may vary greatly in intensity. In the "on" year for a tree with severe biennial bearing, the tree produces a dense bloom

University of Florida, IFAS, Indian River Research and Education Center, Fort Pierce, FL 34945

This research was supported by the Florida Agricultural Experiment Station, and approved for publication as journal series R-09551.

${ }^{1}$ To whom correspondence should be addressed; e-mail ews@ifas.ufl.edu. 
and sets a very large crop of small, inferior fruit, despite the fact that many fruit spontaneously drop from the tree before reaching maturity. In the following "off" year, the tree may set very few fruit or even none at all. The excess of "on" year production may be extreme. For example, Bobb and Blake (1938) describe an apple tree in New Jersey that developed more than 100,000 flowers, although the tree could only be expected to support about 2,500 2.5-inch-diameter $(63.5-\mathrm{mm})$ apples. A mature satsuma mandarin (Citrus reticulata) tree may bear 5,000 to 10,000 flowers, and although natural abscission results in the loss of $80 \%$ of floral units, the $20 \%$ remaining to harvest may still represent an excessive crop (Harty and Sutton, 1992). The biennial cycle can be initiated by various environmental factors, especially growing conditions that severely limit the crop, and once alternate cropping has begun the cycle may persist for years unless overcome by management intervention (Davison, 1966; Wheaton, 1981).

This biennial cycle is problematic for the grower for several distinct reasons: 1) the productivity and profitability of the orchard may fluctuate wildly from year to year, 2) the health and vigor of the tree may be compromised during the "on" year-heavily loaded trees are more sensitive to environmental stress, and limb breakage or even tree collapse may result from the excessive cropload, 3 ) fruit quality may be poor in the "on" year and fruit storage potential may be reduced, and (4) in general, there is a significant negative relationship between fruit size and cropload, and the small fruit produced in abundance in the "on" year are typically less valuable than larger fruit, frequently reducing the cumulative value of fruit on unthinned trees over time. Crop regulation through blossom or fruit thinning can moderate alternate bearing, resulting in more consistent production and improved fruit size as well as increasing fruit quality.

These factors have made thinning a routine practice in apples, pears, and peaches, with growers of these fruits widely recognizing that thinning often increases crop value. Although biennial fluctuation in yield is also evident in many citrus cultivars (Wheaton, 1997), most standard cultivars of orange ( Citrus sinensis), grapefruit (C. paradisi), and lemon (C. limon) are more regular bearers than apples except under adverse fruiting conditions, and common citriculture hedging and pruning practices are generally adequate to prevent excess cropping. Consequently, citrus is seldom thinned in the U.S. However, some cultivars (notably mandarins) are prone to alternation and many of the small fruit produced in the "on" year may be unmarketable, especially in the export market. Thus, interest in the benefits of fruit thinning is increasing among citrus producers.

Most research on thinning appears to proceed on the assumption that greater mean fruit size and/or greater cropload reduction are the ultimate goals of fruit thinning, and studies include little scrutiny of economic consequences. Fruit values and production-related costs vary over time and complicate analysis of the economics of thinning. However, because the economic consequences have received so little attention, relatively little work has been done to identify an optimal target for cropload following thinning or to compare distinct thinning treatments on an economic basis. The purpose of this review is to investigate the published literature as it relates to the economics of thinning and propose guidelines that may make future research even more useful to commercial fruit growers.

HISTORY OF FRUITTHINNING. Through the mid-1900's fruit was thinned almost exclusively by hand, a laborintensive and expensive practice that has become increasingly impractical. Since the 1930s, a variety of chemical thinning agents, primarily plant growth regulators, have been investigated for safety and efficacy, with mixed results. The earliest studies focused on thinning of apples and pears (Auchter and Roberts, 1933). Chemical thinning of citrus has been studied since about 1970 (Wheaton and Stewart, 1973). These compounds are typically applied as a spray or dust at a specified stage in fruit development and either damage some of the blossoms or cause some of the fruitlets to drop from the tree. In fact, the earliest published chemical thinning study was an attempt to identify materials that would entirely prevent fruit set by completely destroying all of the blossoms or buds (Auchter and Roberts, 1933). The thinning response to chemical agents can be highly variable among cultivars and is strongly influenced by environmental conditions. As an extreme example, in tests of the thinning agent ethephon on several cultivars of satsuma mandarins, Harty and Sutton (1992) observed that the response is so variable that each individual property needs to be tested to determine the appropriate application rate. Since these chemical thinners provide a variable response, other work has focused on using follow-up thinning, frequently by hand, to achieve a desired cropload.

Modern fruit thinning studies focus on the relationships between the thinning agent or combination of agents, thinning parameters such as the rate and timing of the application, and the effects on cropload (a measure of fruiting density typically expressed as number of fruit per trunk or branch cross-section area, or per tree canopy volume), fruit size (expressed as weight or diameter), fruit quality, and return bloom (the crop for the following year).

Chemical thinning always carries some risk, as the practice must be completed very early in the season, before the grower can accurately judge crop size or market conditions and before the danger of frost has passed. In addition, some thinning agents may sometimes damage the tree or the surviving fruit. Thinning may also influence various fruit quality factors that affect market grade and value, favorably or unfavorably (e.g., Curry and Greene, 1993; Greene, 1995; Link, 2000; Stover et al., 2002).

Because crop thinning is a horticultural practice intended to address several distinct production issues, the concept of optimal thinning is imprecise and largely intuitive. The grower simultaneously seeks to protect the tree from damage due to excess cropping, ensure adequate return bloom, and increase the number of larger, more valuable fruit both in the current year and subsequent years. A truly optimal thinning strategy integrates these diverse goals to maximize lifetime returns from the tree.

Relationship between fruit Size AND FRUIT VALUE. There is a substantial incentive for growers to reduce cropload to increase fruit size. Large fruit is almost always more valuable than small fruit in the current fresh market, and fresh-packed fruit is almost always more valuable than processing fruit (a major exception is traditional juice oranges in Florida which often receive a 
higher price for processing than fresh use). The premium received for larger fruit varies by fruit cultivar, year, and time of season.

Figure 1 shows prices for various sizes of 'McIntosh' apples in selected seasons since 1976. In March 2001 the largest size available ( 80 to 100 count) sold for $\$ 16.00$ per $11 / 8$-bu (40-L) carton $[\approx 40 \mathrm{lb}(18.1 \mathrm{~kg})]$ while bagged apples sold for only $\$ 10.25$ per carton of $123-\mathrm{lb}$ (1.4-kg) bags. Although the data are incomplete, the premium paid for larger apples appears to have been fairly consistent since 1976. Interestingly, in a conference on chemical thinning of peach and apple in 1959 (Childers), several participants (both growers and researchers) cautioned against over-thinning apples because of the decline in demand for large fruit and high value of smaller fruit, although one participant defined smaller fruit as $23 / 4$ to $3 \frac{1}{4}$ inches $(69.9$ to $82.6 \mathrm{~mm}$ ) in diameter. Figure 2 shows the price paid for standard commercial sizes of 'Murcott' mandarins in mid-February of selected seasons since 1975/1976, illustrating decreasing consumer demand for the smaller sizes over time, especially in the last 10 years. Tangerine prices were almost flat by size in 1976 , but in February 2001 a carton of the largest size mandarins [80s ( 80 fruit per 1 1/8-bu carton)] sold for more than twice that of the smallest [176s (176 fruit per 1 1/8-bu carton)].

ECONOMICS OF FRUIT THINNING. By definition, successful thinning results in a reduction in cropload. In most studies, successful thinning is also reported to increase mean fruit size or to shift the fruit size distribution curve to the larger size categories. Unfortunately, reducing cropload is also likely to reduce yield, generally expressed as weight or cartons of fruit per tree or per land area. Historically, it has been assumed or implied that a significant increase in fruit size will compensate for the loss of yield that typically results from thinning. For example, in 1903 Walker urged peach growers in Arkansas to remove $1 / 2$ to $3 / 4$ of the small fruit, promising that the value of the remaining fruit would be increased sufficiently to pay $1000 \%$ of the cost of thinning, with no reference to the value of the lost fruit. However, it is clear that a reduction in total yield is only beneficial if sufficiently more fruit can be marketed or marketed at a higher price. The actual value of the crop depends on the prevailing prices for each commercial size category (including the value of eliminations - fruit that do not meet minimum standards and may be diverted to the processed market or require disposal), the fruit size distribution, and the total yield. It is important to quantify the economic benefit of thinning and identify croploads that balance the trade-off between yield and fruit size to provide optimal crop value.

\section{Review of literature}

There are many published reports that examine various aspects of fruit thinning. A brief inspection of the cumulative indexes of ASHS journals and proceedings reveals over 200 articles related to thinning between 1903 and 2001, including research on apples, peaches, pears, plums (Prunus domestica), grapes (Vitis spp.), and pecans (Carya illinoensis). Wertheim (2000) cited more than 100 studies since 1950 devoted to thinning of deciduous fruit, primarily apples. Guardiola and Garcia-Luis (2000) cited about 30 studies on citrus thinning since 1975 in their overview of fruit thinning and growth stimulation in citrus. Thinning studies typically report some combination of effects on cropload, fruit size, and/or

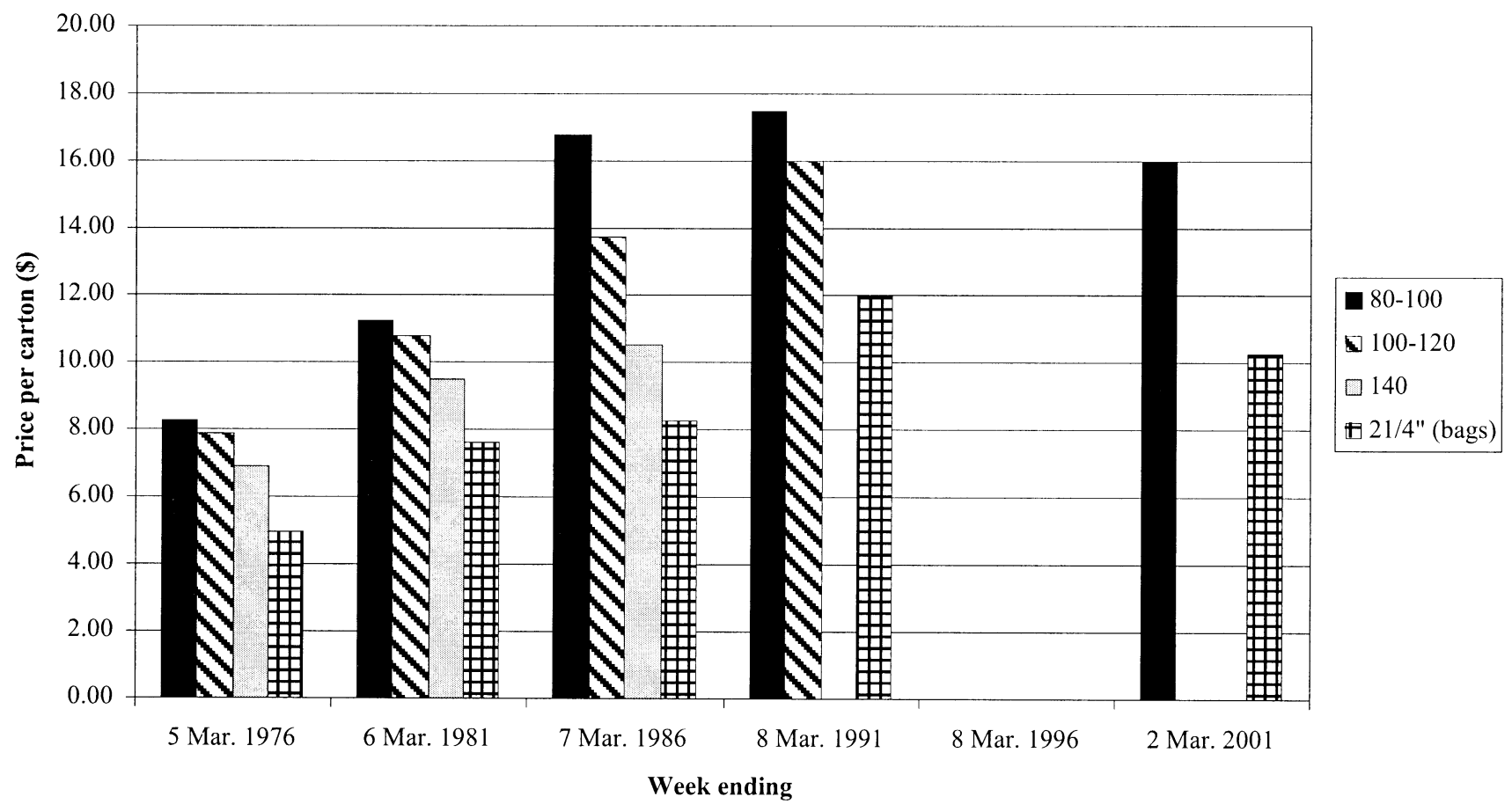

Fig. 1. Farmgate price by size of New York 'McIntosh' apples in early March of selected seasons. Apple sizes refer to the number of apples required to fill a 1 -bu carton $[\approx 40 \mathrm{lb}(\mathbf{1 8 . 1} \mathrm{kg})]$. Apples that do not meet sufficient size for tray packs are sold in 3-lb (1.4-kg) film bags. Cartons of tray-packed 'McIntosh' apples vary in weight from 36 to $39 \mathrm{lb}$ (16.3 to 17.7 $\mathrm{kg}$ ). Bagged apples are packed 12 3-lb bags per carton so a carton of bagged 'McIntosh' apples weighs $36 \mathrm{lb}$ (Stover et al., 2001). Data provided by the U.S. Dept. of Agriculture, Agricultural Marketing Service, Benton Harbor, Mich. (personal communication); 1996 data was not available. 
yield, but in such an array of measures and formats that quantitative evaluations of treatment effects, including comparisons of economic benefits, are difficult if not impossible (e.g., Aznar et al., 1995; Batjer and Westwood, 1960; Brar et al., 1992; Child et al., 1986; Gardner et al., 1961; Greenberg et al., 1992; Greene, 1996, Hirose et al., 1978; Josan and Sharma, 1987; Lavon and Bar-Akiva, 1976; Marini, 1996; Moss and Bevington, 1973; Noma, 1981; Ortola et al., 1991; Palmer et al., 1991; Quinlan and Preston, 1968; Sharma and Awasthi, 1990; Way, 1967; Wheaton and Stewart, 1973).

Forshey and Elfving (1977) commented on the problem of inconsistent and incomplete reporting in thinning research. They observed that although the accumulated data is voluminous, it sheds little light on the relationship between cropload, fruit size, and yield. Only a very small proportion of these papers addressed the economics of cropload reduction at all, and the results of the few systematic attempts to evaluate the economics of thinning have been inconsistent. Some studies showed enhanced crop value in the year of thinning while others showed a loss and many reported mixed results, vary- ing with the specific treatment. A very few studies have attempted to quantify the general relationships between fruit size, cropload, yield, and crop value. The following summarizes some of those reports.

StUdies INWHICH CROPVALUEWASENHANCED IN THE YEAR OF THINNING. Southwick and Weeks (1952) examined the effect of naphthaleneacetic acid (NAA) on several cultivars of apples in Massachusetts. The authors reported that on 'Baldwin', a strongly biennial cultivar, thinned trees produced less total fruit in the year of treatment than unthinned "on-year" trees, but a greater volume and proportion of marketable fruit ( $\geq 21 / 2$ inches diameter). Further, over 2 -years, total yield was slightly greater from thinned trees than from unthinned trees. However, the authors did not quantify the relative value of the fruit from thinned trees compared to unthinned trees in either year.

Gallasch (1978) reported two thinning experiments with ethephon on mature 'Imperial' mandarin trees in Australia, where small fruit were reported to be virtually worthless. The author reported returns to the grower of $\$ 4.78$ per package [0.51 bu ( $18 \mathrm{~L})$ ] for 99 to 120 count fruit versus $\$ 0.98$ per package for 224s. No statistically significant differences in cropload were detected in the first experiment, which involved only 15 trees. In the second experiment, on 35 trees, all thinning treatments increased mean fruit weight and net returns to the grower. Yield was reduced by $16 \%$ to $37 \%$, but grower returns were increased by $44 \%$ to $57 \%$, due to both the tremendously greater value of the larger fruit and harvest savings for the lower yield. Farm-gate value of the fruit was increased by $11 \%$ to $20 \%$ and harvest costs were reduced by $16 \%$ to $37 \%$.

In trials of 2,4-D as a chemical thinner of 'Esbal' clementines, Duarte et al. (1996) reported that mean fruit weight was increased by all thinning treatments by $20 \%$ to $33 \%$ and the effect on yield varied from an increase of $5 \%$ to a decrease of $10 \%$. Fruit set is usually adequate in 'Esbal', but the authors reported that up to $40 \%$ of the crop might be too small for export. In this experiment, commercial yield was increased by all treatments by $25 \%$ to $38 \%$. The authors inferred a marked increase in crop value but the calculations were not shown.

StUdies IN WHich CROP VAlUe WAS REDUCED IN THE YEAR OF THINNING. In a

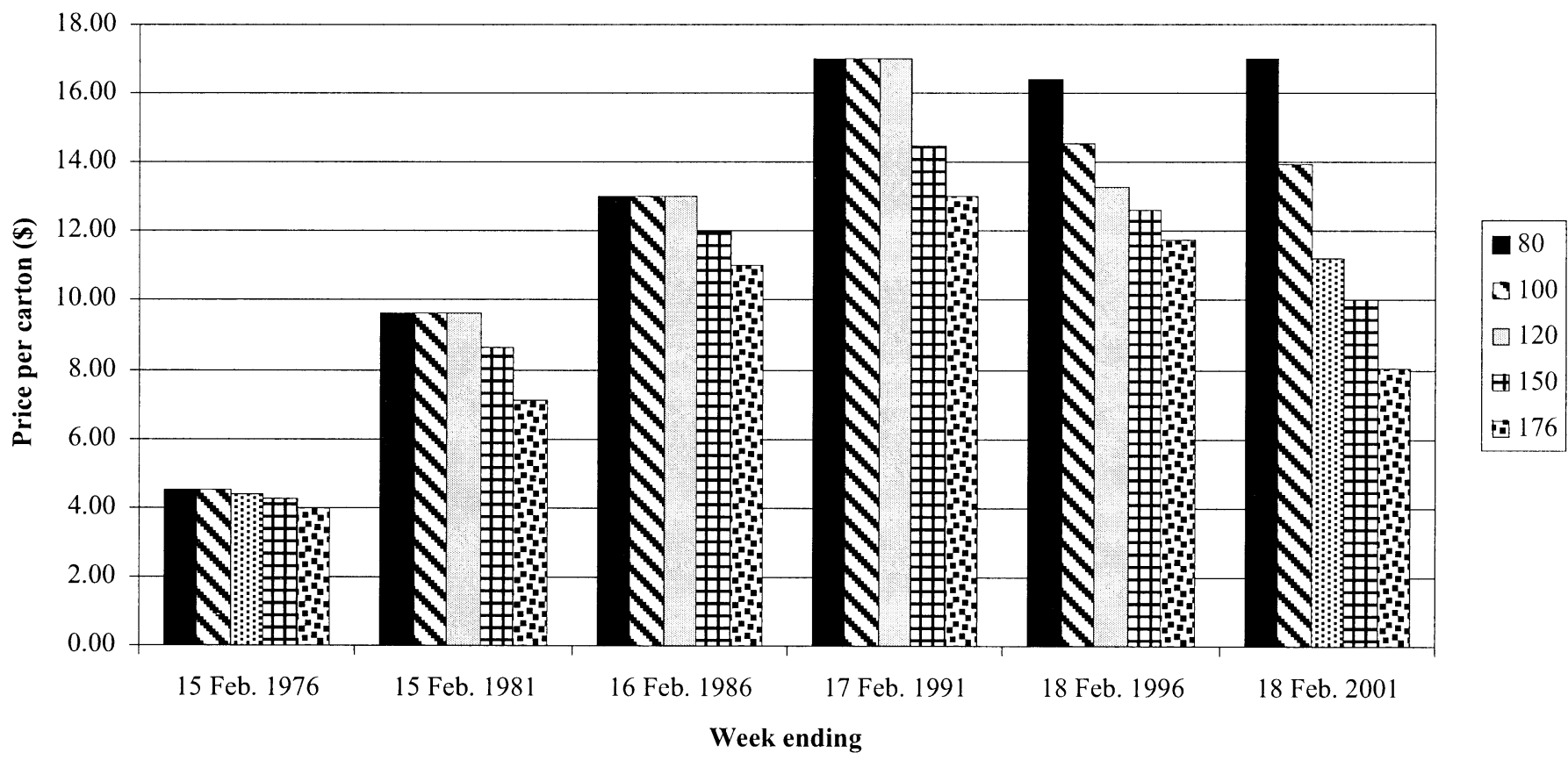

Fig. 2. Price by size of 'Murcott' ('Honey') mandarins in mid-February of selected seasons. Mandarin sizes refer to the number of fruit required to fill a 4/5-bu carton; sizes larger than 80 or smaller than 176 are not normally marketed. A carton of Florida mandarins weighs $\approx 47.5 \mathrm{lb}(21.5 \mathrm{~kg}$ ) (Florida Citrus Administrative Committee, 2003 ). 
study of hand thinning of 'Empire' apples, Silsby et al. (1991) found that improvement in fruit size and quality did not compensate for loss of yield. These studies were conducted in two commercial orchards that had initially been chemically thinned. Supplemental hand-thinning was conducted in each orchard at four postbloom intervals to achieve a uniform cropload in each orchard on each date. Although the proportion of fruit in the larger commercial size categories was significantly increased by all hand-thinning treatments, supplemental thinning resulted in a net loss to the grower of between $1 \%$ and $32 \%$ in seven of the eight treatments. The one exception was an orchard where trees had been unintentionally underthinned, leaving about 30\% more fruit than intended and resulting in a net gain to the grower of $33 \%$. Since this had been viewed as underthinning, the relative gains in this experiment underscore the importance of developing an objective understanding of optimal thinning.

Studies that REPORTED MIXEd REsults. Galliani et al. (1975) tested several thinning procedures comparing applications of NAA, napthaleneacetimide (NAD), ethephon and summer pruning on 'Wilking' mandarins: all treatments increased mean fruit weight, but two of the four treatments increased income by about $30 \%$ compared to the hand-thinning control, another increased income by $8 \%$, and the remaining treatment decreased income by $8 \%$.

Monselise et al. (1981) reported several experiments thinning three mandarin cultivars, 'Wilking', 'Michal', and 'Murcott', by hand and with NAA and ethephon. Mean fruit weight was consistently increased, but the change in grower profit varied from a $31 \%$ increase to a $52 \%$ decrease. The most significant losses were reported for 'Murcott', which is a large-fruited cultivar. The authors concluded, "If most of the fruit of on-trees can be marketed, every loss in yield is important in reducing profit."

Cook (1985) examined postproduction gains and losses (revenue less costs associated with or affected by thinning, including harvest, transportation and packing) from thinning 'Starkrimson Delicious' apples by hand alone and by application of NAA with and without supplemental hand-thinning. The effect of the treatments on post-production income ranged from a decrease of $22 \%$ to an increase of $15 \%$ compared to the unthinned control. The only increase in income resulted from the application of NAA without supplemental hand-thinning; application of NAA followed by handthinning resulted in an $11 \%$ loss, even though mean fruit size was increased, and hand-thinning without the application of NAA resulted in 22\% lower post-production income. It should be noted that the statistical significance of these differences is not reported. The author concluded "Our results show that [supplemental hand-thinning] can actually reduce income under some conditions. Where heavy cropping may cause limb breakage, thinning is warranted regardless of the effect upon the current year's crop. However, hand thinning guarantees neither larger fruit nor greater income when cropload is moderate."

Gallasch (1988) reported three experiments testing various thinning procedures involving NAA and ethephon on different mandarin cultivars and examined 2-year postproduction returns to the grower (the year of thinning and the following year) based on prevailing price by size for mandarins. In every thinning trial, mean fruit size was increased in the year of thinning, but returns to the grower were decreased in that year. However, the effects of thinning on 2-year returns to the grower were highly variable. In the first experiment, on 'Ellendale', only one of four treatments increased 2 -year returns, and that only by $1 \%$, while losses ranged from $10 \%$ to $15 \%$. In the second experiment, on 'Dancy', three of four treatments increased 2year returns by $7 \%$ to $89 \%$, with a loss in one treatment of $20 \%$. In the third experiment, on 'Imperial', all five thinning treatments reduced 2 -year returns to the grower, by $14 \%$ to $32 \%$.

McNeil et al. (1994) examined the economics of fruit thinning of California 'Olinda Valencia' oranges with NAA. Every treatment increased yield in the largest fruit size category and decreased total yield. The economic value of each treatment was assessed assuming two scenarios: 1) fresh packing of all four commercial fruit sizes $(88,113,138$, and 163 counts or number of fruit per $11 / 8$ bu carton), or 2) fresh packing of the two largest sizes and processing of the two smaller sizes. Processing of $50 \%$ to $90 \%$ of the smaller sizes may occur in years of excess supply. In the first situation, assuming all four sizes were marketed fresh, all thinning treatments resulted in a net loss to the grower of between $6 \%$ and $11 \%$. That is, the shift in fruit size distribution toward large and more valuable fruit did not compensate for the loss in total yield. However, in the second situation, assuming the smaller sizes were diverted to the less profitable processed market, two of three treatments resulted in a net gain to the grower of $4 \%$ to $10 \%$. The remaining treatment represented a loss to the grower of $3 \%$.

StUdies in WHich CROP VAlUe WAS ENHANCED IN A 2-YEAR CYCLE. Hutton (1992) showed commercial packout of late 'Valencia' oranges thinned with ethephon. The author reported that fruit thinning at application rates that achieved uniformity in consecutive harvests shifted the size distribution of fruit toward the larger size classes in the "on" year, although the change in median fruit size at those rates was not more than 6\%. Two-year yields were increased by up to $16 \%$ by the thinning treatments. The author claimed that the cost of implementing this management strategy could be more than offset in the first crop after spraying, due to the premium paid for larger fruit.

Kallsen (2001) applied petroleum oil as a thinning agent for 'Bonanza Navel' orange over 3 years. The treatments shifted the fruit size distribution toward larger commercial size categories in the 2 later years, with no thinning effect in the first year of treatment. However, a comparison of crop value per acre, using the prevailing price by size in each year, showed a loss of $7 \%$ in the first year, followed by a gain of $44 \%$ the following year, for a 2 -year increase of $10 \%$. A much greater premium was paid for large fruit in the second year, with size 56 worth twice as much as size 138 in the first year and almost three times as much in the second year. Eliminations were not included in the calculations for either year, but the author estimated that savings resulting from fewer eliminations offset the direct cost of thinning.

Stover et al. (2002) examined the economics of thinning 'Murcott' mandarins. Despite substantial cropload reduction and increase in production of larger fruit, there was little effect of thinning on crop value within the year of thinning. However, trees thinned 
with NAA had markedly higher yields than the controls in the following year. Better return cropping in the "off-year" appears to have substantially increased cumulative 2-year returns.

STUDIES OF THE FUNDAMENTAL CROPLOAD RELATIONSHIPS. Several authors have taken a more comprehensive approach and attempted to identify underlying patterns in the economics of thinning by examining the general relationships between fruit size, cropload, yield and crop value. Forshey and Elfving (1977) collected data from three 'McIntosh' orchards: one that was thinned by hand, one thinned with NAA, and one left unthinned. They found that yield was so closely related to cropload that a single regression line accurately described the relationship for all three orchards. They also reported a negative correlation of fruit size with yield and with cropload, but these relationships were significantly different for each orchard. In the two thinned orchards, fruit size distribution was significantly altered by moderate thinning with mean fruit weight increased by $9 \%$ to $19 \%$. However, since the increase in fruit size did not compensate for reductions in fruit numbers, thinning was associated with significant reductions in yield. They concluded that thinning beyond a moderate level is counterproductive and thinning should be limited to the minimum that ensures acceptable fruit quality and adequate repeat bloom. They also noted that reports of an increased percentage of fruit in the larger categories, or a shift in the distribution of fruit size, are misleading and that actual yield in each size category is critical.

Dennis et al. (1983) examined the relationship between fruit size and cropload in 'Starkrimson Delicious' apples. They plotted mean fruit size against cropload in seven orchards and observed a close negative relationship in six of the seven. They noted that in the remaining orchard fruit size was much larger than would be expected from cropload but offered no explanation. The fruit size distribution in relation to cropload in three of these orchards was also plotted and the authors noted that in one of the orchards the cropload was heavy and many fruit were too small for commercial use, in another the cropload was light and increased fruit size did not compensate for low fruit numbers. The third orchard was characterized as ideal in yield and fruit size- - however, this was the anomalous orchard noted above in which fruit size was larger than expected. Economic data were not shown for any of the three orchards.

Bergh (1990) developed a regression equation for fruit value/ton as a function of several growth parameters, including mean fruit size and cropload for four apple cultivars, using prevailing price by size for each cultivar. The results were inconsistent. For 'Starking' and 'Granny Smith', mean fruit size was positively correlated with fruit value/ unit weight and significant $(P=0.05)$ but there was no significant correlation for 'Golden Delicious' or 'Starkrimson'. Similarly, there was a significant positive correlation between cropload and value for 'Starking' but the coefficient was negative and significant $(P$ $=0.05$ ) for both 'Golden Delicious' and 'Starkrimson'. Graphing the relationship between mean fruit size, crop value, and yield showed that crop value/land area increased to a maximum as yield increased and fruit size decreased; crop value then decreased as yield continued to increase and mean fruit size continued to decrease. That is, there was an optimum cropload and associated fruit size. Croploads that produced either smaller or larger mean fruit size would therefore reduce crop value. Both 'Golden Delicious' and 'Starkrimson' apple production exhibited this pattern, but an optimum level of production to maximize crop value could not be identified for the other two cultivars, 'Granny Smith' and 'Starking'. The author indicated that it would be difficult to maintain production of these cultivars at higher croploads than those observed, so the optimum was not likely to be achieved. The actual cropload and fruit size corresponding to maximum crop value depend on the prevailing price by size distribution for the cultivar. The effect of thinning on return bloom and consequently the value of the following year's crop was not included in the analysis.

Stover et al. (2001) developed a method for evaluating the response curve of crop value vs. cropload that permits identification of a production level to maximize crop value per orchard area. Examples were provided for individual blocks of apples and citrus, but the method appears to be applicable to any fruit or nut crop. The response curve method also makes it possible to compare effects of different thinning practices on fruit value. Significantly, in the apple trials reported, the optimum cropload was often greater than that likely to ensure good return bloom, and usually occurred at the cropload that provided the greatest total yield (not percent yield) of the most valuable fruit size. Thus, thinning to increase fruit size beyond that required for management of alternate bearing was counter-productive. This finding underscores the danger of focusing solely on mean fruit size and cropload reduction, because these factors can appear to improve even as total production of the most valuable fruit declines, since production of smaller fruit declines more quickly as cropload is reduced. For the citrus examples reported, the curve was relatively flat near the maximum, indicating that citrus growers have a wide range of near-optimal croploads, within the year of thinning.

\section{Conclusions}

Fruit thinning is intended to address both horticultural and economic concerns as the grower simultaneously seeks to protect the tree from damage due to excess cropping, ensure adequate return bloom, and increase the number of larger, more valuable, fruit both in the current year and subsequent years. Hundreds of fruit thinning experiments, at a likely cost of thousands of dollars each, have been conducted and reported for various fruits including apple, pear, and citrus, with an emphasis on chemical thinning dating to the 1930s for apples and pears and the 1970s for citrus. Researchers routinely report significant cropload reduction accompanied by an increase in fruit size; the effect on total yield varies, but is generally negative in the year of thinning.

While these reports have greatly advanced our understanding of thinning methodology, very few attempt to evaluate the economic implications of cropload reduction and they seldom include sufficient information for a retrospective economic analysis. Variable values for fruit in different size categories and changes in harvesting and packing costs can completely alter the relative economic returns from a group of thinning treatments, and this has likely persuaded many authors to avoid economic analyses. However, exclusion of data on important cropping parameters makes it impossible 
to extract economic projections from most papers describing thinning experiments. Although increased fruit size and reduced cropload are crucial responses to thinning treatments, they do not provide sufficient information to permit economic analysis. The value of the crop depends on the yield of fruit in each commercial size category and the prevailing prices for each category, as well as specific costs associated with production, harvest, and packing. Routine inclusion of total yields with either fruit size distributions or mean fruit sizes and standard deviations would provide at least minimal capabilities for economic assessments and comparison of distinct treatments. In addition, since alternate bearing is routinely invoked as a major rationale for thinning, and there is evidence to suggest that cumulative returns may be increased even if the grower experiences a loss in the year of thinning, studies should provide data on multiple year responses to thinning treatments or strategies.

The few economic studies summarized in this review illustrate that the economic effects of fruit thinning vary widely and successful thinning, resulting in reduced cropload and increased fruit size, often reduces returns to the grower. Further, those studies that have examined the relationship between cropload and crop value suggest that thinning beyond that required to regulate bearing may be excessive and counter-productive, even though fruit size may be substantially increased. It is important to quantify the economic benefit of thinning and identify croploads that balance the trade-off between yield and fruit size to provide optimal crop value.

\section{Literature cited}

Auchter, E.C. and J.W. Roberts. 1933. Experiments in spraying apples for the prevention of fruit set. Proc. Amer. Soc. Hort. Sci. 30:22-25.

Aznar, M., V. Almela, M. Juan, M. ElOtmani, and M. Augusti. 1995. Effect of the synthetic auxin phenothiol on fruit development of 'Fortune' mandarin. J. Hort. Sci. 70:617-621.

Batjer, L.P. and M.N. Westwood. 1960. 1-Naphthyl $\mathrm{N}$-methylcarbamate, a new chemical for thinning apples. Proc. Amer. Soc. Hort. Sci. 75:1-4.

Bergh, O. 1990. Proposed regression model for calculating optimum crop levels of apple trees. South African J. Plant and Soil 7:19-25.

Bobb, A.C. and M.A. Blake. 1938. Annual bearing in the 'Wealthy' apple was induced by blossom thinning. Proc. Amer. Soc. Hort. Sci. 36:321-327.

Brar, S.S., P.P.S. Minhas, and G.S. Kaundal. 1992. Chemical thinning of 'Kinnow' mandarin. Acta Hort. 321:443-448.

Child, R.D., J.S. Adam, H.A. Atkins, and G.M. Arnold. 1986. The effects of annual fruit thinning with carbaryl on fruit size and yield in 'Cox's Orange Pippin' apples. Acta Hort. 179:705-706.

Childers, N.F. (ed.). 1959. Chemical fruit thinning of peach and apple. N.J. Agr. Expt. Sta., Rutgers Univ., New Brunswick.

Cook, R.L. 1985. Does supplemental hand thinning pay? Annu. Rpt. Mich. State Hort. Soc. 115:181-185.

Curry, E.A. and D.W. Greene. 1993. CPPU influences fruit quality, fruit set, return bloom, and preharvest drop of apples. HortScience 28:115-119.

Davison, R.M. 1966. Chemical thinning of apples in New Zealand. N.Z. Dept Scientific and Ind. Res. Info. Ser. 60.

Dennis, Jr., F.G. 2000. The history of fruit thinning. Plant Growth Regulat. 31:1-16.

Dennis, Jr., F.G., D.R. Dilley, and R. Cook. 1983. Improving fruit quality and yield. Proc. Mich. State Hort. Soc. 113: 198-202.

Duarte, A.M.M., D.T.G. Trindade, and J.L. Guardiola. 1996. Thinning of 'Esbal' clementine with 2,4-dichlorophenoxyacetic acid: influence on yield, fruit size and fruit quality. Proc. Intl. Soc. Citriculture 2:929-933.

Florida Citrus Administrative Committee. 2003. Annual statistical report. Selected seasons, 1975/1976-2000/2001. 26 Jan. 2004. <http://www.citrusadminis trativecommittee.org/shippersreport/ annualreport/annual_special.pdf>.

Forshey, C.G. and D.C. Elfving. 1977. Fruit numbers, fruit size, and yield relationships in 'McIntosh' apples. J. Amer. Soc. Hort. Sci. 102:399-402.

Gallasch, P.T. 1978. Thinning 'Imperial' mandarins with ethephon increases fruit size and grower returns. Proc. Intl. Soc. Citricult. 1:276-279.

Gallasch, P.T. 1988. Chemical thinning of heavy crops of mandarins to increase fruit size. Proc. 6th Intl. Citrus Congr. p. 395-405.

Galliani, S., S.P. Monselise, and R. Goren. 1975. Improving fruit size and breaking alternate bearing in 'Wilking' mandarins by ethephon and other agents. HortScience $10: 68-69$

Gardner, F.E., P.C. Reece, and G.E. Horanic. 1961. Thinning of 'Dancy' tangerines at blossom time with maleic hydrazide. Proc. Amer. Soc. Hort. Sci. 77:188-193.

Greenberg, J., Y. Hertzano, and G. Eshel. 1992. Effects of 2,4-D, ethephon and NAA on fruit size and yield of 'Star Ruby' red grapefruit. Proc. Intl. Soc. Citricult. 1: 520-523.

Greene, D.W. 1995. Thidiazuron effects on fruit set, fruit quality, and return bloom of apples. HortScience 30:1238-1240.

Greene, D.W. 1996. Influence of CPPU on fruit quality and storage potential of 'McIntosh' apples. J. Tree Fruit Prod. 1: 87-97.

Guardiola, J.L. and A. Garcia-Luis. 2000. Increasing fruit size in citrus: thinning and stimulation of fruit growth. Plant Growth Regulat. 31:121-132.

Harty, A.R. and P.G. Sutton. 1992. Crop regulation of 'Satsuma' mandarin in New Zealand. Proc. Intl. Soc. Citricult. 2: 729-734.

Hirose, K., I. Iwagaki, and K. Suzuki. 1978. IZAA (5-chloroindazol-8-acetic acid ethyl ester) as a new thinning agent of 'Satsuma' mandarin. Proc. Intl. Soc. Citricult. 1:270-273.

Hutton, R.J. 1992. Improving fruit size and packout of 'Late Valencia' oranges with ethephon fruit thinning sprays. Austral. J. Expt. Agr. 32:753-758.

Josan, J.S. and J.N. Sharma. 1987. Chemical thinning of 'Wilking' mandarin. Indian J. Hort. 44:172-175.

Kallsen, C.E. 2001. Petroleum oils as 'Navel' orange fruit thinning agents. HortTechnology 11:189-193.

Lavon, R. and A. Bar-Akiva. 1976. Mineral nutrients as thinning agents in 'Wilking' mandarin trees. HortScience 11:419-420.

Link, H. 2000. Significance of flower and fruit thinning on fruit quality. Plant Growth Regulat. 31:17-26.

Marini, R.P. 1996. Chemically thinning spur 'Delicious' apples with carbaryl, NAA, and ethephon at various stages of fruit development. HortTechnology 6: 241-246.

McNeil, R.J., K.C. Johnston, K.W. Johnson, and R.W. Smith. 1994. A demonstration of the economics and effectiveness of 1-naphthaleneacetic acid (NAA) for fruit thinning of 'Valencia' orange, p. 21-33. Proc. 6th Ann. Conf.Western Plant Growth Regulat. Soc. 
Monselise, S.P., E.E. Goldschmidt, and A. Golomb. 1981. Alternate bearing in citrus and ways of control. Proc. Intl. Soc. Citricult. 1:239-242.

Moss, G.I. and K.B. Bevington. 1973. Methods for controlling biennial bearing in 'Late Valencia' sweet orange, p. 367-372. I Congreso Mundial de Citricultura.

Noma, Y. 1981. Effect of ethyl 5-chloro$1 \mathrm{H}-3$-indazolylacetate on fruit thinning of 'Satsuma' mandarin. Proc. Intl. Soc. Citricult. 1:271-275.

Ortola, A.G., C. Monerri, and J.L. Guardiola. 1991. The use of naphthalene acetic acid as a fruit growth enhancer in 'Satsuma' mandarin: A comparison with the fruit thinning effect. Sci. Hort. 47:15-25.

Palmer, J.W., Y.L. Cai, and Y. Edjamo. 1991. Effect of part-tree flower thinning on fruiting, vegetative growth and leaf photosynthesis in 'Cox's Orange Pippin' apple. J. Hort. Sci. 66:319-325.

Quinlan, J.D. and A.P. Preston. 1968. Effects of thinning blossom and fruitlets on growth and cropping of sunset apple. J. Hort. Sci. 43:373-381.

Sharma, R.K. and R.P. Awasthi. 1990. Effect of growth regulators on crop regulation in Kinnow. Punjab Hort. J. 30:22-26.

Silsby, K.J., T. Robinson, and F. Dellamano. 1991. 'Empire' hand thinning study. Proc. New York State Hort. Soc. 136: 175-186.
Southwick, F.W. and W.D. Weeks. 1952. The influence of chemical thinning treatments on yield and flowering of apples. Proc. Amer. Soc. Hort. Sci. 60:165-172.

Stover, E., F. Wirth, and T. Robinson. 2001. A method for assessing the relationship between cropload and crop value following fruit thinning. HortScience 36:157-161.

Stover, E., S. Ciliento, M. Ritenour, and C. Counter. 2002. NAA thinning of 'Murcott': comparison of small plot and commercial harvest data. Proc. Florida State Hort. Soc. 115:287-291.

Walker, E. 1903. Peach growing in Arkansas. Ark. Agr. Expt. Sta., Fayetteville, Bul. 79 .

Way, D.W. 1967. Carbaryl as a fruit thinning agent, II: Concentration and time of application. J. Hort. Sci. 42:355-365.

Wertheim, S.J. 2000. Developments in the chemical thinning of apple and pear. Plant Growth Regulat. 31:85-100.

Wheaton, T.A. 1981. Fruit thinning of Florida mandarins using plant growth regulators. Proc. Intl. Soc. Citricult. 1: 263-268.

Wheaton, T.A. 1997. Alternate bearing of citrus in Florida, p. 87-92. In: S.H. Futch and W.J. Kender (eds.). Citrus flowering and fruiting short course. Fla. Agr. Expt. Sta., Citrus Res. Educ. Ctr., Univ. Fla., Inst. Food Agr. Sci., Lake Alfred.

Wheaton, T.A. and I. Stewart. 1973. Fruit thinning of tangerines with naphthaleneacetic acid. Proc. Florida State Hort. Soc. 86:48-52. 